Supporting Information

\title{
Multitag-Regulated Cascade Reaction: A Generalizable Ultrasensitive MicroRNA Biosensing Approach for Cancer Prognosis
}

Ruoyu Wang ${ }^{\dagger}$, Xiyu Zhu ${ }^{\dagger}$, Yunpeng Xing ${ }^{\dagger}$, Abdul Ghaffar Memon ${ }^{\dagger}$, Hanchang Shi ${ }^{\dagger}$ and Xiaohong $\mathrm{Zhou}^{\dagger^{*}}$

${ }^{\dagger}$ State Key Joint Laboratory of ESPC; Center for Sensor Technology of Environment and Health School of Environment, Tsinghua University, Beijing 100084, China.

${ }^{*}$ Corresponding author e-mail: xhzhou@ mail.tsinghua.edu.cn. 


\section{Experimental Section}

\section{Materials and instruments}

Reagents. Quartz optical-fiber (6 $\mathrm{cm}$ in length, $600 \mu \mathrm{m}$ in diameter) was purchased from Chunhui Science \& Technology Industrial Co., China. The optical-fibers were etched to tapered-structures by hydrofluoric acid (HF) before further chemical modification. Streptavidin (SA), desthiobiotin (DTB), EZ-link NHS-desthiobiotin (NHS-DTB), PBS buffer packs and streptavidin-coupled magnetic beads (MBs, $1 \mu \mathrm{m}$ diameter, $10 \mathrm{mg} / \mathrm{mL}$ ) were purchased from Thermo Fisher Scientific Company. Bovine serum albumin (BSA), (3-mercaptopropyl)trimethoxysilane (MTS), (3-Aminopropyl)triethoxysilane (APTS), 4-maleimidobutyric acid N-hydroxysuccinimide ester (GMBS), sodium citrate $\left(\mathrm{Na}_{3} \mathrm{C}_{6} \mathrm{H}_{5} \mathrm{O}_{7} \cdot 3 \mathrm{H}_{2} \mathrm{O}\right)$, citric acid $\left(\mathrm{C}_{6} \mathrm{H}_{8} \mathrm{O}_{7} \cdot \mathrm{H}_{2} \mathrm{O}\right)$, sodium chloride $(\mathrm{NaCl})$, tris- $\mathrm{HCl}$ and formamide were purchased from Sigma-Aldrich company. RNA Lysis buffer was purchased from Promega (Z3051). Amicon Ultra 3K and 10K centrifugal filters were from Merck Millipore, Life Science. Cy5.5-ester was obtained from GE Healthcare, Life Sciences. Cy5.5 labeled SA (SA-F) was synthesized according to previously reported method, and the labeling ratio was calculated to be 8 based on UV measurements. ${ }^{[1]}$ All acids and other organic solvents were purchased from Beijing Chemical Works. All aqueous solutions were prepared using molecular biology grade USP sterile purified water (Corning Cellgro, NY, USA).

Cancer patient samples. Urine samples of patients with non-small cell lung cancer (NSCLC) and unspecified lung cancer (USLC) were collected from Beijing Aizhen hospital ( $=9$ ) and Beijing Cancer Hospital $(\mathrm{N}=9)$, respectively.

Oligonucleotides. All nucleic acid oligonucleotides (HPLC-purified) were purchased from Sangon Biotechnology Co. Ltd. (Shanghai, China), as listed in Table S1. The design of hairpin sequences are refered to the work of Ma et.al. ${ }^{[2]}$

\section{Buffers}

PBS buffer: $100 \mathrm{mM}$ PBS, $150 \mathrm{mM} \mathrm{NaCl}, \mathrm{pH}$ 7.4;

Equilibration buffer: $10 \mathrm{mM}$ PBS buffer, $15 \mathrm{mM} \mathrm{NaCl}, \mathrm{pH}$ 7.4; SPSC buffer: $0.75 \mathrm{M} \mathrm{NaCl}, 50 \mathrm{mM} \mathrm{Na} 2 \mathrm{HPO}_{4}, \mathrm{pH} 7.4$;

Washing buffer: $0.05 \%$ SDS, $\mathrm{pH} 1.9$;

Isoelectric BSA blocking solution: $2 \mathrm{mg} / \mathrm{mL}$ of BSA in $0.1 \mathrm{M}$ citrate buffer, $\mathrm{pH} 4.6$;

Instruments. Fluorescence (FL) spectra were obtained by Hitachi F-7000 spectrometer. Unless specified otherwise, the excitation wavelength for FAM and Cy5.5 are set at $495 \mathrm{~nm}$ and $675 \mathrm{~nm}$, respectively. UV absorbances were measured by Hitachi U-3900 spectrometer. The optical-fiber 
diameter was monitored with a microelectrode polisher (model 2002-C, Inbio Life Science Instrument Co., Ltd., Hubei, China). Atomic force microscopy (AFM) measurements were carried out using Bruke (Dimension edge) at Tianhe Scientific Center.

\section{Optical-fiber based fluorescent biosensor}

The newly developed optical-fiber biosensor consumes less reagents and is more automated than previously developed ones. ${ }^{[3]}$ There are two major updates for this biosensor: (1) the manual injection system has been replaced with an automatic injection system; (2) A small-sized cylindrical flow cell is used. The minimum volume needed for each sample injection is $250 \mu \mathrm{L}$ (decreased by $44 \%$ ) compared to previously developed prototypes. The pump speed in sample injection and elution processes is set at $12 \mu \mathrm{L} / \mathrm{s}$ during the whole study.

\section{Verification of TSD1 and TSD2 processes}

First of all, $5 \mu \mathrm{M}$ of hairpin strands ( $\mathrm{H} 1$ beacon, $\mathrm{H} 1$ and $\mathrm{H} 2-\mathrm{F}$ ) were individually denatured at $90{ }^{\circ} \mathrm{C}$ for $5 \mathrm{~min}$, and then cooled at room temperature $\left(25^{\circ} \mathrm{C}\right)$ for over an hour to obtain annealed hairpins.

For TSD1 verification, $5 \mathrm{nM}$ of In was added into $50 \mathrm{nM}$ of annealed $\mathrm{H} 1$ beacon in $1 \mathrm{~mL}$ SPSC buffer, the obtained solution was incubated at $25^{\circ} \mathrm{C}$ for different times (30-150 min) before FL measurement. For TSD2 verification, $5 \mathrm{nM}$ of Bio-In was added into $1 \mathrm{~mL}$ SPSC buffer containing annealed H1 (50 $\mathrm{nM})$ and $\mathrm{H} 2-\mathrm{F}(50 \mathrm{nM})$, the solution was incubated at $25^{\circ} \mathrm{C}$ for $1 \mathrm{~h}$. Next, $50 \mu \mathrm{L}$ of $10 \mathrm{mg} / \mathrm{mL}$ streptavidin-coupled magnetic beads (MBs) was added into the solution to capture biotinylated MCR assemblies (AB), and the MB-involved mixture was gently rotated for 20 min at $25^{\circ} \mathrm{C}$. Then the ABconjugated MBs were separated from unreacted hairpins using a magnetic stack, and the supernatant was collected for further FL measurement.

\section{Characterization of MCR assemblies by AFM measurements and gel electrophoresis}

AFM Measurement. MCR assemblies for AFM characterization was prepared by incubating $0.5 \mu \mathrm{M}$ Bio-In, $5 \mu \mathrm{M}$ Bio-H1 and $5 \mu \mathrm{M}$ H2-F at room temperature for $48 \mathrm{~h}$ (Bio-H1 and H2-F were independently annealed). For AFM control group, only $5 \mu \mathrm{M}$ Bio-H1 and $5 \mu \mathrm{M}$ H2-F are mixed at room temperature for $48 \mathrm{~h}$. Then the obtained mixture containing MCR assemblies (MCR mixture) was stored at $4{ }^{\circ} \mathrm{C}$ before AFM measurements. For AFM measurements, a freshly cleaved mica surface was prepared for sample mounting. Next, $40 \mu \mathrm{L}$ of $0.5 \%$ APTS aqueous solution was added to the center of the mica surface for $2 \mathrm{~min}$. The mica surface was cleaned with water and dried in air. Then $20 \mu \mathrm{LMCR}$ mixture was added to the center of the mica surface and dried in air for AFM measurements. The sample was scanned under tapping mode. 
Native Gel Electrophoresis. A $15 \%$ freshly prepared polyacrylamide gel was prepared with 5× TBE buffer. Electrophoresis was run at $60 \mathrm{~V}$ for $1 \mathrm{~h}$ in $1 \times$ TBE buffer. Gels were stained with GelRed Acid Gel Stain (Biotium, US) and imaged under UV illumination using FLS-5100 film (Fuji Photo Film Co., Ltd., Tokyo, Japan).

\section{Preparation of DTB functionalized optical-fiber sensing surface}

Firstly, DTB-labeled BSA (BSA-DTB) was synthesized using BSA and N-Hydroxysuccinimide (NHS)-activated desthiobiotin (NHS-DTB) as starting materials (Figure S2). Initially, $10 \mathrm{mM}$ NHSDTB in DMF and $1 \mathrm{mg} / \mathrm{mL}$ BSA ( $\left.\mathrm{c}_{0}\right)$ in $100 \mathrm{mM}$ PBS buffer were prepared as stock solutions. (Please note that this labelling reaction must be conducted using amine-free buffer such as PBS at $\mathrm{pH}$ 7.2-8.0.) To investigate the optimal labeling ratio, $0 \mathrm{X}, 5 \mathrm{X}, 10 \mathrm{X}, 15 \mathrm{X} 50 \mathrm{X}$ and $75 \mathrm{X}$ molar excess of NHS-DTB to BSA were incubated with $1 \mathrm{mg} / \mathrm{mL} \mathrm{BSA}$ ( $\left.c_{\text {before }}\right)$ in PBS buffer for $1 \mathrm{~h}$ at $25^{\circ} \mathrm{C}(0 \mathrm{X}$ as blank control). During the incubation, NHS moiety reacted efficiently with primary amine groups of BSA to form stable amide bonds. After that, unreacted NHS-DTB molecules were removed out of the system by Amicon-10K centrifugal filter $\left(4^{\circ} \mathrm{C}, 12000 \mathrm{rpm}, 8\right.$ times $)$. After purification, the synthesized BSADTB were collected and diluted to $1 \mathrm{~mL}$. The protein recoveries could be calculated based on the changes of UV absorbance at the characteristic peak $(278 \mathrm{~nm})$ of BSA before (Abs.before) and after (Abs.after) Amicon purification. Recovery = Abs.after/Abs.before based on Beer-Lambert law (Table 2), and the concentration of BSA after purification $\left(c_{\mathrm{f}}\right)$ can be calculated by $c_{\mathrm{f}}=$ recovery $\times c_{0}$.

Taking advantages of remaining amine groups, BSA-DTB could be covalently modified onto the optical-fiber surface based on previously reported protocols with slight changes. ${ }^{[4]}$ Before surface modification, the tapered optical-fiber was cleaned in hot piranha solution $\left(\mathrm{v} / \mathrm{v} \mathrm{H}_{2} \mathrm{SO}_{4}: 30 \% \mathrm{H}_{2} \mathrm{O}_{2}=\right.$ 3:1). As shown in Figure S3, the cleaned fiber was first immersed in $2 \%$ MTS toluene solution for 2 $\mathrm{h}$ at $25^{\circ} \mathrm{C}$. Next, sulfhydryl activated fiber was immersed in $1 \mathrm{mg} / \mathrm{mL}$ GMBS ethanol solution for $1 \mathrm{~h}$ at $25{ }^{\circ} \mathrm{C}$. Finally, the GMBS-fiber was incubated with $0.05 \mathrm{mg} / \mathrm{mL}$ BSA-DTB $(0-75 \mathrm{X})$ at $4{ }^{\circ} \mathrm{C}$ overnight. Before usage, the DTB-fiber was further blocked in isoelectric BSA blocking solution for more than 6 hours to reduce nonspecific adsorption. ${ }^{[5]}$

\section{Detection of miR in buffer/human urine using the optical-fiber based biosensor}

For miR detection in SPSC buffer using MCR approach, different concentrations of let-7a were incubated with independently annealed Bio-H1 and H2-F (both $1 \mu \mathrm{M}$ ) in $1 \mathrm{~mL}$ SPSC buffer at room temperature $\left(25^{\circ} \mathrm{C}\right)$ for $4 \mathrm{~h}$. For its monotag-regulated control group, Bio-I and H1 were used instead. The optical-fiber based detection proceeded as follows: (1) $20 \mathrm{nM}$ of unlabeled SA was first pumped into the flow cell to react with DTB surface for $2 \mathrm{~min}$; (2) then unbound SA were washed off by SPSC 
buffer elution; (3) MCR assemblies were pumped into the flow cell and designed to reacted with surface-bound SA for $10 \mathrm{~min}$; (4) SDS washing buffer containing SDS was pumped into the flow cell to wash off surface bound SA together with MCR assemblies; (5) Equilibration buffer was pumped into the flow cell to regenerate the sensing surface for next round of detection. All original sensorgrams are presented without deducting the baseline.

Human urine samples pretreatment: After fresh urine collection in hospital, $0.1 \% \mathrm{v} / \mathrm{v}$ of RNA lysis buffer was immediately added into the urine samples to resist possible enzymatic degradation. After gently but sufficiently mixing, the samples were frozen at $-80{ }^{\circ} \mathrm{C}$ before further treatment.

Detection miR in human urine samples: Firstly, urine samples were unfrozen to room temperature. For each test, $0.5 \mathrm{~mL}$ of urine sample was concentrated to $30 \mu \mathrm{L}$ using Amicon-3K centrifugation (12000 $\mathrm{rpm}, 4{ }^{\circ} \mathrm{C}$ ). $1 \mu \mathrm{L}$ of the concentrated urine was added into $9 \mu \mathrm{L}$ of SPSC buffer, and the obtained solution was incubated with independently annealed $\mathrm{H} 1$ and $\mathrm{H} 2$ (both $1 \mu \mathrm{M}$ ) in $1 \mathrm{~mL}$ SPSC buffer at room temperature $\left(25^{\circ} \mathrm{C}\right)$ for $4 \mathrm{~h}$. The following detection procedure was the same as the above. The statistical significance of the net signals obtained from different groups of urinary samples were analyzed by Origin 9.0 using One-Sample t-Test.

\section{Logistic fitting of the calibration curve}

Normalized net signals (NNS) were used in preparing the calibration curve, which was fitted with a four-parameter Logistic model using Origin 9.0:

$$
S=\frac{\mathrm{A}_{1}-\mathrm{A}_{2}}{1+\left([c] /\left[c_{0}\right]\right)^{\mathrm{p}}}+\mathrm{A}_{2}
$$

Where $[c]$ represents analyte concentration; $S$ represents normalized net signal (NNS), $\left[c_{0}\right]$ represents the analyte concentration at the midpoint or infection point (IC50); and $p$ is the slope of the tangent at IC50. $A_{1}$ and $A_{2}$ represent the minimum and maximum signal of the calibration curve, respectively. Linear working range was defined as analyte concentrations corresponding to $20 \%-80 \%$ of the maximal signal $\left(\mathrm{A}_{2}\right)$; Limit of detection (LOD) was defined as the analyte concentration corresponding to $10 \%$ of the maximal signal (i.e. NNS $=10 \%$ ).

The fitted parameters corresponding to Figure 4D are:

$$
\mathrm{A}_{1}=-15.7 \pm 3.7 ; \mathrm{A}_{2}=114.9 \pm 3.9 ; c_{0}=0.28 \pm 0.06 ; \mathrm{p}=0.25 \pm 0.02\left(\mathrm{R}^{2}=0.99971\right)
$$

The calculated LOD and linear range are:

$$
\text { LOD }=0.8 \mathrm{fM} \text {; Linear range: } 1 \mathrm{fM}-71 \mathrm{pM}
$$




\section{Supplementary Tables}

Table S1 Sequences used in this developed MCR approach

\begin{tabular}{|c|c|}
\hline Name & Sequence ( $\left.5^{\prime}-3{ }^{\prime}\right)$ \\
\hline Bio-In & Biotin-TGAGGTAGTAGGTTGTATAGTT \\
\hline \multirow[t]{2}{*}{ H1 } & AGTAGGTTGTATAGTTCAAAGTAACTATACAACCT \\
\hline & ACTACCTCA \\
\hline \multirow[t]{2}{*}{ Bio-H1 } & AGTAGGTTGTATAGTTCAAAGTAACTATACAACCT \\
\hline & ACTACCTCA-biotin \\
\hline \multirow[t]{2}{*}{ H1 beacon } & 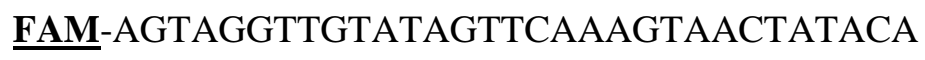 \\
\hline & ACCTACT $\underline{(\mathbf{B H Q 1})}$ ACCTCA \\
\hline \multirow[t]{2}{*}{$\mathrm{H} 2-\mathrm{F}$} & Cy5.5-ACTTTGAACTATACAACCTACTTGAGGTAGT \\
\hline & AGGTTGTATAGTT \\
\hline Hsa-let-7a & UGAGGUAGUAGGUUGUAUAGUU \\
\hline Hsa-let-7b & UGAGGUAGUAGGUUGU $\underline{\mathbf{G}} \underline{\mathbf{G} G U U}$ \\
\hline Hsa-let-7e & UGAGGUAGGAGGUUGUAUAGU \\
\hline Hsa-let-7f & UGAGGUAGUAG \\
\hline Hsa-let-7g & 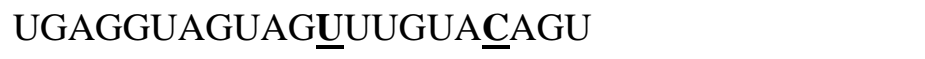 \\
\hline Hsa-let-7i & 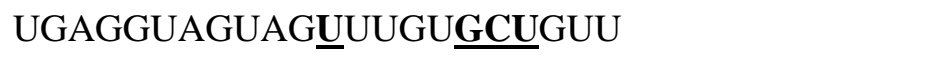 \\
\hline Hsa-miR-122a & UGGAGUGUGACAAUGGUGUUUG \\
\hline Hsa-miR-151a & CUAGACUGAAGCUCCUUGAGG \\
\hline Hsa-miR-181a & AACAUUCAACGCUGUCGGUGAGU \\
\hline
\end{tabular}


Table S2 Protein recovery rates of different BSA-DTB conjugates

\begin{tabular}{cccc}
\hline DTB/BSA molar ratio & Abs.278 nm & Recovery $(\%)$ & $\mathrm{c}_{\mathrm{f}}(\mathrm{mg} / \mathrm{mL})$ \\
\hline $0 \mathrm{X}$ & 0.592 & 88 & 0.88 \\
$5 \mathrm{X}$ & 0.556 & 83 & 0.83 \\
$10 \mathrm{X}$ & 0.550 & 82 & 0.82 \\
$15 \mathrm{X}$ & 0.584 & 87 & 0.87 \\
$50 \mathrm{X}$ & 0.553 & 82 & 0.82 \\
$75 \mathrm{X}$ & 0.546 & 81 & 0.81 \\
\hline
\end{tabular}


Table S3 Sensing performances of some reported miR assays/biosensors

\begin{tabular}{|c|c|c|c|c|c|}
\hline Entry & Platform & Method & LOD & $\begin{array}{l}\text { Cancer patient } \\
\text { sample application }\end{array}$ & Ref. \\
\hline 1 & $\begin{array}{l}\text { optical-fiber } \\
\text { FL biosensor }\end{array}$ & $\begin{array}{l}\text { multitag-regulated reaction } \\
\text { (MCR), enzyme-free }\end{array}$ & $0.8 \mathrm{fM}$ & YES & this work \\
\hline 2 & $\begin{array}{l}\text { homogeneous } \\
\text { FL assay }\end{array}$ & T4 RNA ligase involved & $10 \mathrm{fM}$ & NO & Ref. 6 \\
\hline 3 & $\begin{array}{l}\text { homogeneous } \\
\text { FL assay }\end{array}$ & $\begin{array}{l}\text { polymerase-assisted } \\
\text { exponential amplification } \\
\text { reaction (EXPAR) }\end{array}$ & $0.01 \mathrm{fM}$ & NO & Ref. 7 \\
\hline 4 & on-particle & $\begin{array}{l}\text { exonuclease III-powered } \\
\text { stochastic DNA walker }\end{array}$ & $10 \mathrm{fM}$ & NO & Ref. 8 \\
\hline 5 & $\begin{array}{l}\text { homogeneous } \\
\text { FL assay }\end{array}$ & $\begin{array}{l}\text { photoinduced electron } \\
\text { transfer, rolling circle } \\
\text { amplification }\end{array}$ & $6 \mathrm{aM}$ & YES & Ref. 9 \\
\hline 6 & $\begin{array}{l}\text { electrochemical } \\
\text { biosensor }\end{array}$ & $\begin{array}{l}\text { enzyme-based isothermal } \\
\text { exponential amplification }\end{array}$ & $98.9 \mathrm{fM}$ & NO & Ref. 10 \\
\hline 7 & $\begin{array}{l}\text { localized surface } \\
\text { plasmon resonance } \\
\text { (LSPR) sensor }\end{array}$ & $\begin{array}{l}\text { gold nanoprisms modified } \\
\text { LSPR surface }\end{array}$ & $23-35 \mathrm{fM}$ & YES & Ref. 11 \\
\hline 8 & $\begin{array}{l}\text { nanophotonic } \\
\text { biosensor }\end{array}$ & $\begin{array}{l}\text { direct detection, } \\
\text { amplification-free }\end{array}$ & $23 \mathrm{aM}$ & YES & Ref. 12 \\
\hline 9 & nanopore-based & $\begin{array}{l}\text { alpha-hemolysin protein } \\
\text { based, amplification-free }\end{array}$ & $0.1 \mathrm{pM}$ & YES & Ref. 13 \\
\hline 10 & $\begin{array}{l}\text { electrochemical } \\
\text { biosensor }\end{array}$ & $\begin{array}{l}\text { magnetobiosensors based } \\
\text { on viral protein } 19\end{array}$ & $0.04 \mathrm{nM}$ & YES & Ref. 14 \\
\hline 11 & $\begin{array}{l}\text { DNA logic gate } \\
\text { platform }\end{array}$ & $\begin{array}{l}\text { near-infrared } \mathrm{Ag}_{2} \mathrm{~S} \\
\text { quantum dots-based DNA } \\
\text { logic gate }\end{array}$ & $12.0 \mathrm{fM}$ & NO & Ref. 15 \\
\hline 12 & $\begin{array}{l}\text { electrochemical } \\
\text { biosensor }\end{array}$ & $\begin{array}{l}\text { gold-loaded nanoporous } \\
\text { superparamagnetic iron } \\
\text { oxide nanocubes (Au- } \\
\mathrm{NPFe}_{2} \mathrm{O}_{3} \mathrm{NC} \text { ) }\end{array}$ & $100 \mathrm{aM}$ & YES & Ref. 16 \\
\hline 13 & $\begin{array}{l}\text { electrochemical } \\
\text { biosensor }\end{array}$ & $\begin{array}{l}\text { gold-loaded nanoporous } \\
\text { superparamagnetic } \\
\text { nanocubes }\end{array}$ & $100 \mathrm{fM}$ & YES & Ref. 17 \\
\hline 14 & $\begin{array}{l}\text { electrochemical } \\
\text { biosensor }\end{array}$ & $\begin{array}{l}\left(\mathrm{Au} @ \mathrm{NPFe}_{2} \mathrm{O}_{3} \mathrm{NC}\right) \text { for } \\
\text { signal amplification } \\
\text { poly(A) extension } \\
\text { strategy, } \\
\text { amplification-free }\end{array}$ & $10 \mathrm{fM}$ & YES & Ref. 18 \\
\hline
\end{tabular}




\section{Supplementary Figures}

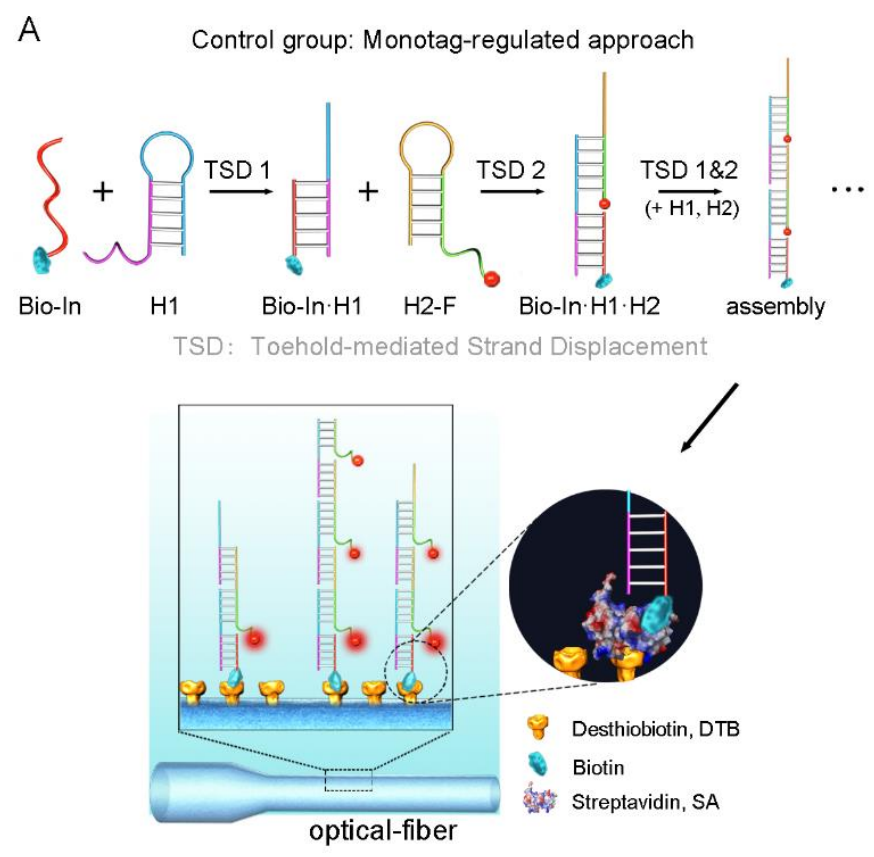

B

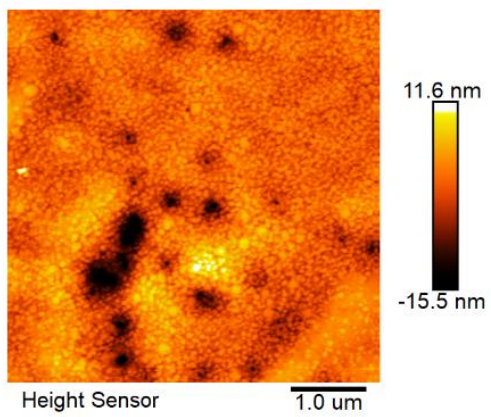

Figure S1 (A) Schematic illustration of the monotag-regulated approach (control group of MCR). (B) Control AFM image (mixture of $\mathrm{H} 1$ and $\mathrm{H} 2$ in the absence of In). No linear assemblies can be observed without adding In.

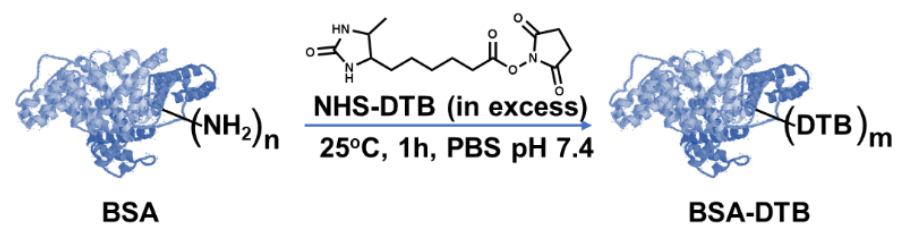

Figure S2 Schematic illustration of the synthesis reaction of BSA-DTB conjugate 


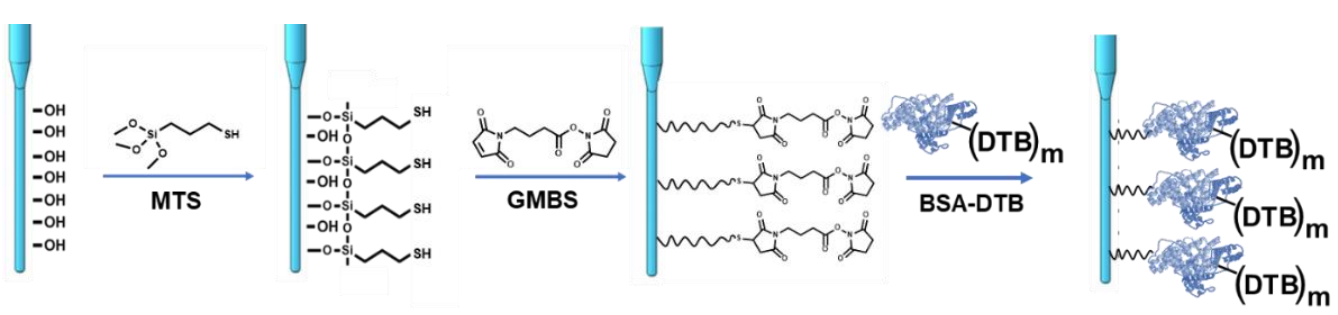

Figure S3 Schematic illustration of the preparation of DTB functionalized optical-fiber

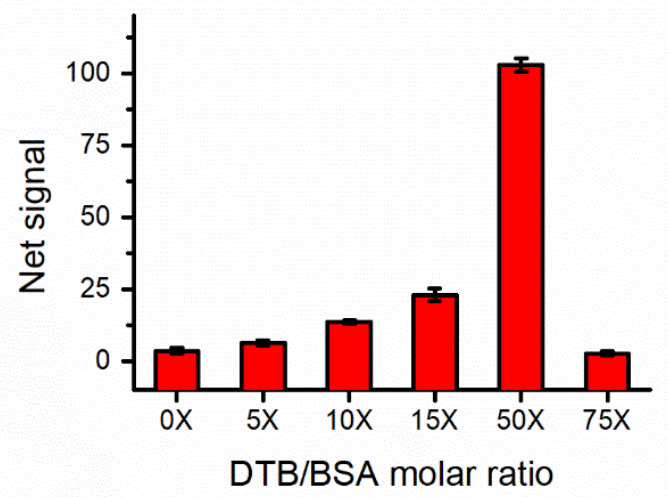

Figure S4 Net signals induced by $15 \mathrm{nM}$ of SA-F (in $1 \mathrm{~mL}$ SPSC buffer) on optical fibers modified with different types of BSA-DTB conjugates (0X-75X)

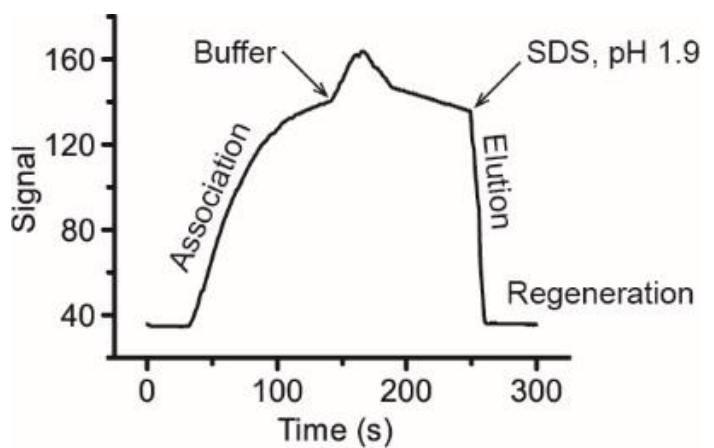

Figure S5 Sensorgram during the association, buffer washing and elution of $15 \mathrm{nM}$ SA-F 


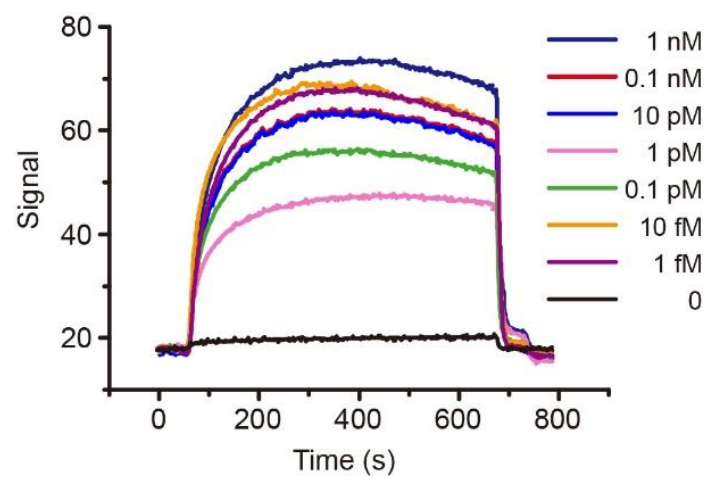

Figure S6 Origianl sensorgrams corresponding to Figure 4C

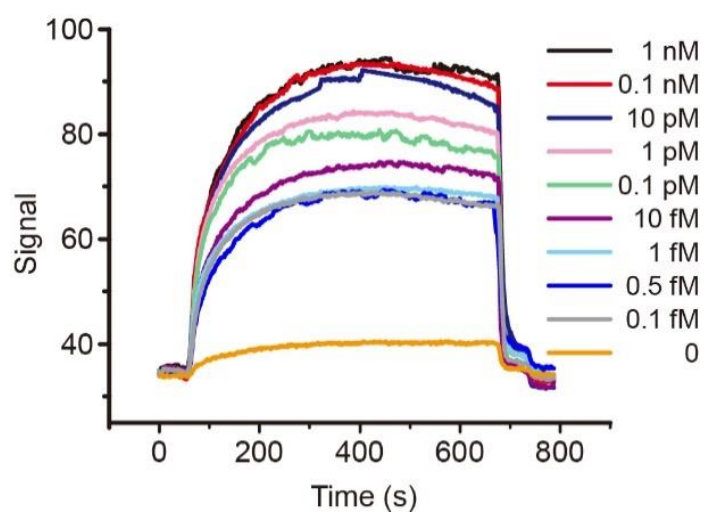

Figure S7 Origianl sensorgrams corresponding to Figure 4D

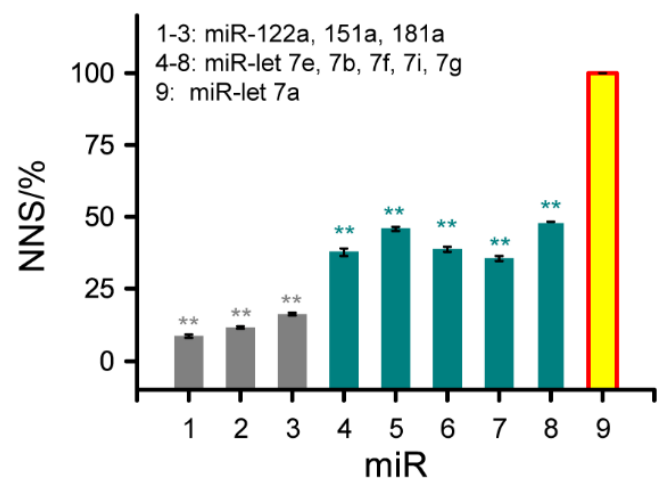

Figure S8 Selectivity of the developed MCR approach. $\mathrm{c}(\mathrm{miR})=1 \mathrm{nM}$ for all miRs. NNS = normalized net signal (signals generated by 0 and $1 \mathrm{nM}$ of let-7a were set as 0 and 100\%, respectively). For group 1-3 (miR-122a, 151a and 181a), $p=0.05$; For group 4-8 (miR-let 7e, 7b, 7f, 7i and 7g), $p=0.01$. 


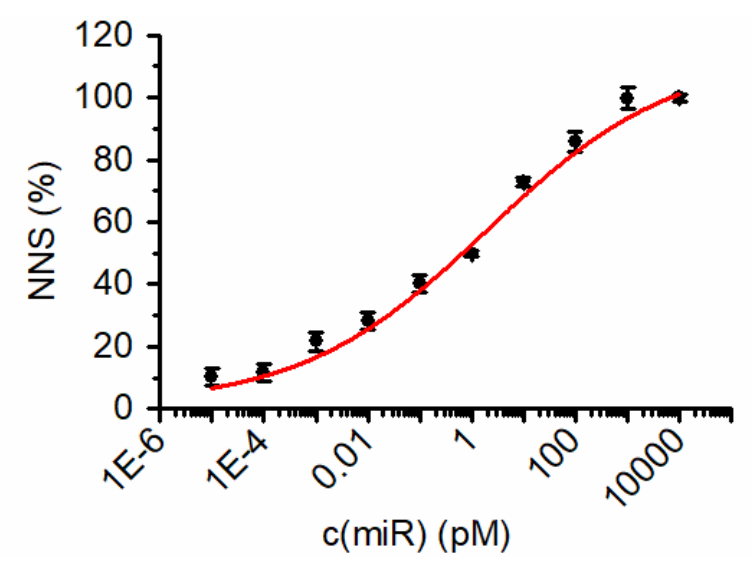

Figure S9 Normalized net signals (NNS) against different concentrations of miR in urine samples

The fitted parameters corresponding to Figure S9 are: $\mathrm{A}_{1}=1.0 \pm 2.4 ; \mathrm{A}_{2}=113.8 \pm 7.2 ; c_{0}=1.99 \pm$ $1.28 ; \mathrm{p}=0.24 \pm 0.04\left(\mathrm{R}^{2}=0.99058\right)$.

The calculated LOD and linear range are:

$$
\text { LOD }=0.1 \mathrm{fM} \text {; Linear range: } 6 \mathrm{fM}-614 \mathrm{pM}
$$

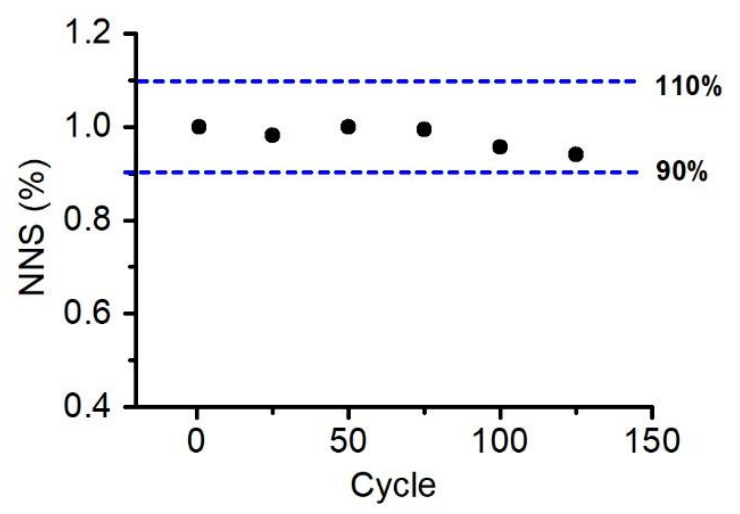

Figure S10 Normalized net signals (NNS) against $4 \mathrm{nM}$ of SA-F in different regeneration cycles $\left(1^{\text {st }}\right.$, $25^{\text {th }}, 50^{\text {th }}, 75^{\text {th }}, 100^{\text {th }}$ and $\left.125^{\text {th }}\right)$ with a standard deviation $2.5 \%$. 


\section{References}

(1) L. H. Liu, X. H. Zhou, W. Q. Xu, B. D. Song, H. C. Shi, RSC Adv. 2014, 4, 60227-60233.

(2) C. Ma, H. Liu, T. Tian, X. Song, J. Yu, M. Yan, Biosens. Bioelectron. 2016, 83, 15-18.

(3) a) R. Y. Wang, Y. Xiang, X. H. Zhou, L. H. Liu, H. C. Shi, Biosens. Bioelectron. 2015, 66, 11 18; b) R. Y. Wang, X. H. Zhou, H. C. Shi, Biosens. Bioelectron. 2015, 74, 78-84. c) F. Long, M. He, H. C. Shi, A. N. Zhu, Biosens. Bioelectron. 2008, 23, 952-958.

(4) L. Liu, X. Zhou, Y. Lu, D. Shan, B. Xu, M. He, H. Shi, Y. Qian, Biosens. Bioelectron. 2017, 97, 16-20.

(5) R. Y. Wang, X. H. Zhou, X. Y. Zhu, C. Yang, L. H. Liu, H. C. Shi, ACS Sens. 2017, 2, $257-$ 262.

(6) Y. Cheng, X. Zhang, Z. Li, X. Jiao, Y. Wang, Y. Zhang, Angew. Chem., Int. Ed. 2009, 48, 3268-3272.

(7) H. Jia, Z. Li, C. Liu, Y. Cheng, Angew. Chem., Int. Ed. 2010, 49, 5498-5501.

(8) X. Qu, D. Zhu, G. Yao, S. Su, J. Chao, H. Liu, X. Zuo, L. Wang, J. Shi, L. Wang, W. Huang, H. Pei, C. Fan, Angew. Chem., Int. Ed. 2017, 56, 1855-1858.

(9) F. Zhou, R. Meng, Q. Liu, Y. Jin, B. Li, ChemistrySelect 2016, 1, 6422-6428.

(10) Y. Yan, D. Zhao, T. Yuan, J. Hu, D. Zhang, W. Cheng, W. Zhang, S. Ding, Electroanalysis 2013, 25, 2354-2359.

(11) G. K. Joshi, S. Deitz-McElyea, M. Johnson, S. Mali, M. Korc, R. Sardar, Nano Lett. 2014, 14, 6955-6963.

(12) C. S. Huertas, D. Fariña, L. M. Lechuga, ACS Sens. 2016, 1, 748-756.

(13) Y. Wang, D. Zheng, Q. Tan, M. X. Wang, L.Q. Gu, Nat. Nanotech. 2011, 6, 668-674.

(14) S. Campuzano, R. M. Torrente - Rodríguez, E. López-Hernández, F. Conzuelo, R. Granados, J. M. Sánchez-Puelles, J. M. Pingarrón, Angew. Chem., Int. Ed. 2014, 53, 6168-6171.

(15) Miao, P.; Tang, Y.; Wang, B.; Meng, F., Near-Infrared $\mathrm{Ag}_{2} \mathrm{~s}$ Quantum Dots-Based DNA Logic Gate Platform for MiRNA Diagnostics. Anal. Chem. 2016, 88, 7567-7573.

(16) Islam, M. N.; Masud, M. K.; Nguyen, N. T., Gopalan, V.; Alamri, H. R.; Alothman, Z. A.; Hossain, M. S. A.; Yamauchi, Y.; Lam, A. K.; Shiddiky, M. J. A., Gold-Loaded Nanoporous Ferric Oxide Nanocubes for Electrocatalytic Detection of MicroRNA at Attomolar Level. Biosens. Bioelectron. 2018, 101, 275-281.

(17) Masud, M. K.; Islam, M. N.; Haque, M. H.; Tanaka S.; Gopalan, V.; Alici, G.; Nguyen, N. T., Lam, A. K.; Hossain, M. S. A.; Yamauchi, Y.; Shiddiky, M. J. A., Gold-Loaded Nanoporous Superparamagnetic Nanocubes for Catalytic Signal Amplification in Detecting MiRNA. Chem. Commun. 2017, 53, 8231-8234. 
(18) Koo, K. M.; Carrascosa, L. G.; Shiddiky, M. J. A., et al. Poly (A) Extensions of MiRNAs for Amplification-Free Electrochemical Detection on Screen-Printed Gold Electrodes. Anal. Chem., 2016, 88, 2000-2005. 